\title{
Engineer Leandro Badarán's project to safeguard the fortresses of Alicante in 1794
}

\author{
V. Echarri \\ Department of Building Construction, University of Alicante, Spain
}

\begin{abstract}
After the construction of the San Carlos bastion in Alicante in the final decade of the seventeenth century, and the great trench which the English built around the district of San Francisco during their years of dominance in the War of Succession, the waters of the San Blas gully caused serious damage to these fortifications of the city and to the trade buildings of the port. In 1772, the diversion canal was built. It was designed to divert the riverbed of the gully and send the waters directly to the sea. The project had been initially designed by the Engineer General, Jorge Próspero de Verboom in 1721. This unique work of engineering had some defects, principally in the breakwater which prevented the waters from flowing down the former river course. On several occasions, the water returned to its original riverbed due to the weakness of the breakwater, the narrowness of the channel's bed and its lack of regularisation, causing serious damage to the bastion, the Babel-facing façade, the traders' warehouses and other buildings. This study describes the project that the military engineer Leandro Badarán carried out in 1794 in order to technically improve this canal and examines his report on the state of the fortifications. Similar works built in Spain are also explained. It also analyses the repeated disputes between the war department and the port throughout these years over finding a technical solution to the problem.
\end{abstract}

Keywords: fortifications, military engineers, Jorge Próspero de Verboom, Leandro Badarán, Francisco Sabatini, Alicante. 


\section{Introduction}

"It was said in good humour that this competition was 'like doctors, one contradicts the other causing further damage and harm to the sick,"'. SHM. Col. Aparici, t. I, fol. 202.

At times, the fortification of bastions meant that rivers and water sources had to be channelled and diverted, a practice that mainly affected Mediterranean coastal cities. After the summer, swift flowing torrents of water caused considerable damage to ditches and foundations, and as a result stretches of wall and other fortification works collapsed. In the 18th century this situation worsened, as when cities and towns needed to expand and protect themselves sometimes water courses and small gullies were incorporated within their walls and at times these could increase and overflow. These channelling works were carried out by military engineers whose competence covered a wide range of building skills, and they were expert in public works and fortifications. The plans that they drew up for the fortified walls of cities addressed all these aspects in a standardised manner. The technical training of these engineers was given an enormous boost following the arrival in Spain of the Engineer General Jorge Próspero de Verboom in 1709 [1]. His technical knowledge and experience gained in the Low Countries, a land of canals, locks and innumerable hydraulic engineering works was decisive in this field.

\section{Hydraulic engineering works in Spain}

During the reign of Philip II, hydraulic engineering works were planned and supervised by military engineers [2]. At this time the work of Juanelo Turriano was important as he was responsible for the devising the system that brought the waters of the Tagus up to Toledo. The works of containment to control the river flow, the Tibi reservoir close to Alicante was another unique example of engineering. Work was begun in 1580 by Juan Bautista Antonelli, with his cousin Cristóbal Antonelli, continuing the task and it became the most important reservoir of its time in the known world. Following the developments in Holland and Belgium during the 17 th and 18th centuries [3], works were carried out in Spain to channel rivers, divert water sources and create dams or build breakwaters and other projects in sea ports. This was often for commercial reasons as the works made navigation much easier for shipping, and in other cases, such as that which concerns us here, the purpose was to prevent damage to urban constructions, especially their fortifications.

During the 18th century following Verboom's arrival in Spain, some significant works were carried out. This experience of this engineer, who was born in Antwerp and who trained at the Military Academy in Brussels alongside Sebastián Fernández de Medrano, and had taken part in the campaigns from 1691-1698 with Van Coehoorn, and in the campaigns of the War of Succession in the Low Countries with Sebastián le Prestre de Vauban, was decisive in training Spanish engineers of the time [4]. 


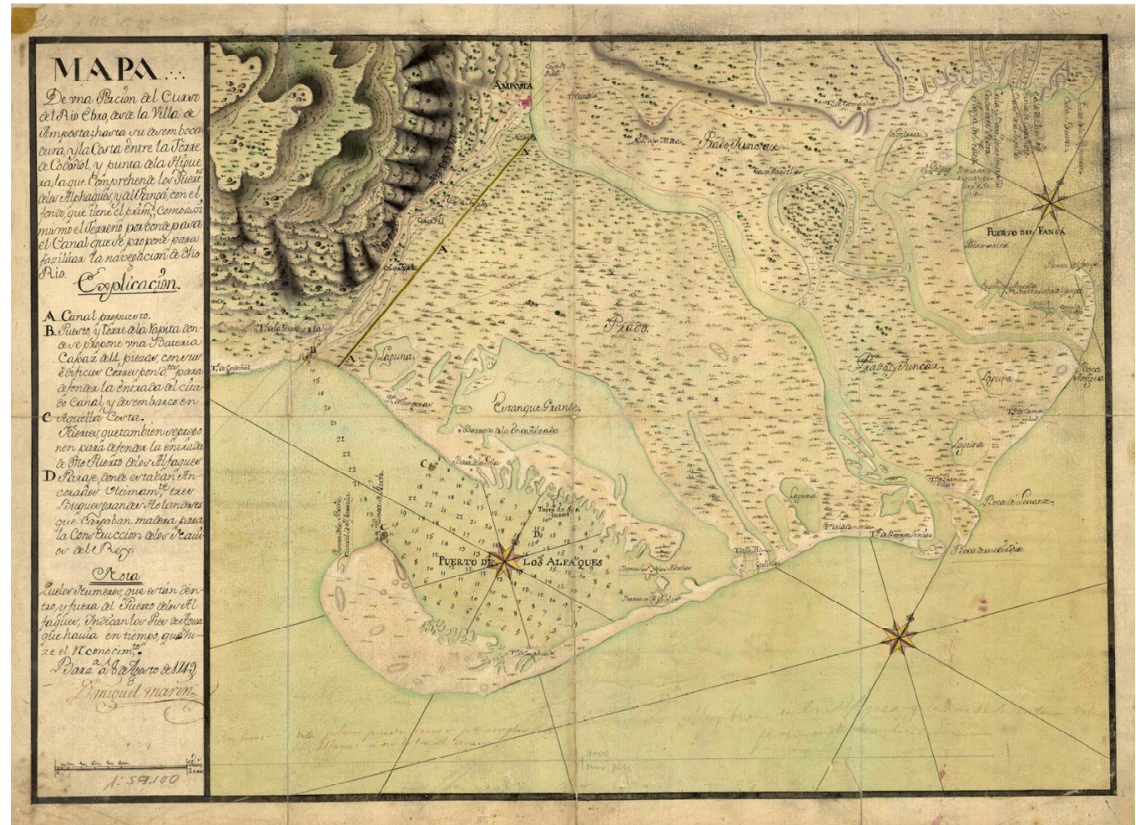

Figure 1: Canal for navigating the river Ebro in 1749, SGE, Ar.F-T.8-C.3-319.

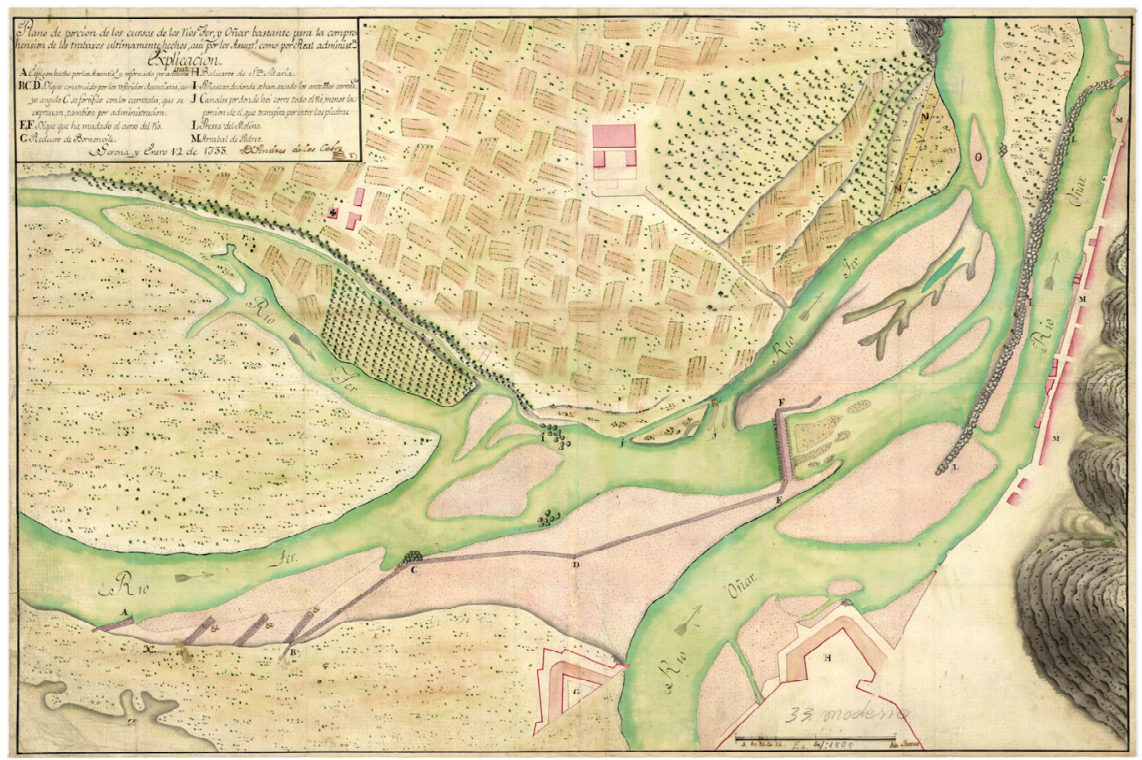

Figure 2: Diversion of the rivers Ter and Oñar, 1733, SGE, Ar.F-T.8-C.3-582. 
Verboom planned and directed some of these engineering works and devised and supervised many more. Following his death in 1744, in the second half of the 18 th century a few projects to divert river sources were implemented, mainly at the river mouth. One of these projects was in the vicinity of Amposta at the mouth of the river Ebro in 1749 (Fig. 2), designed to allow the passage of ships, resulting in several projects directed by Juan Martín Zermeño; works were carried out in El Puerto de Santa María in 1721, a project planned by Ignacio Sala in order to channel the river Guadalete to its former source; diversion of the river Ter where it passes by the Bournonville fortress and the bastion of Santa María in Gerona, planned by Andrés de los Cobos in 1733; the diversion of the watercourses affecting the fortifications and the port of Cartagena (Fig. 4), which was the work of Sebastián Feringán in 1747; the diversion of the rivers Castril and Guardal [5]; diversion of the waters of the river Gudalmedina, which affected the port of Málaga in 710; or the project for Alicante which concerns us here and which will be detailed below. Important canal projects were carried out for irrigation purposes, such as that of Seu de Urgell in 1751, the Imperial canal in Aragón in 1778, the irrigation canal from Andalucía to Murcia in 1787, and navigation works such as those of the Guadalquivir in 1780 .

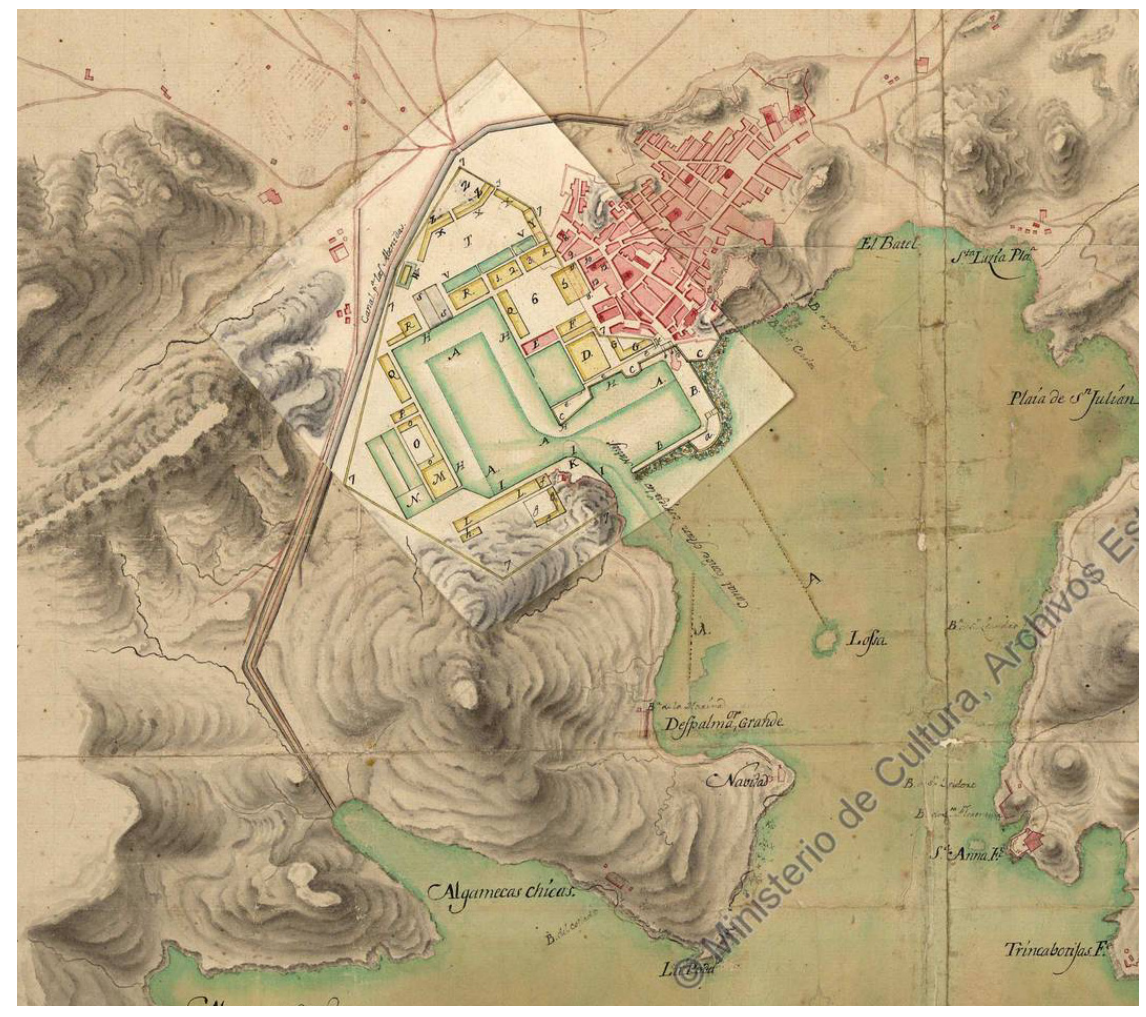

Figure 3: Canal for diverting water courses in Cartagena, AGS M, P and D. IV-077. 


\section{The Alicante city walls and the San Blas and Canicia earthworks}

During the 16th century the Alicante city walls comprised long curtains and circular bastion towers which could house artillery. Constructed in the reign of Charles V, it was one of the most striking walled fortifications in the Iberian peninsula. Towards the end of the century the castle of Santa Bárbara, set on the natural height of Benacantil, was reinforced by a bastion front designed by Jacobo Palear Fratín, Philip II's great engineer [6]. In this way Alicante's fortifications were maintained up until the 17th century within the limits defined by the earthworks of San Blas and Canicia. Thus the heavy flows produced by torrential rains at the end of the summer did not affect their buildings or fortifications.

In the last years of the 18th century, work was begun on extending and modernising the fortifications. Trade had considerably increased and with it numerous warehouses and other buildings had been built outside the walls, mainly in the San Francisco neighbourhood [7]. The city walls built in the time of Charles $\mathrm{V}$ were no longer able to provide adequate resistance to the siege tactics of the "Vauban era" and the might of new artillery. The most notable project was that designed by Ambrosio Borçano, Senior Engineer and Quarter Master General of the Catalonian army. However, expansion of the fortifications was accelerated following bombardment of the city by the French fleet in 1691 . Borçano planned and directed the work on a new bastion facing Bavel beach: the San Carlos bastion.

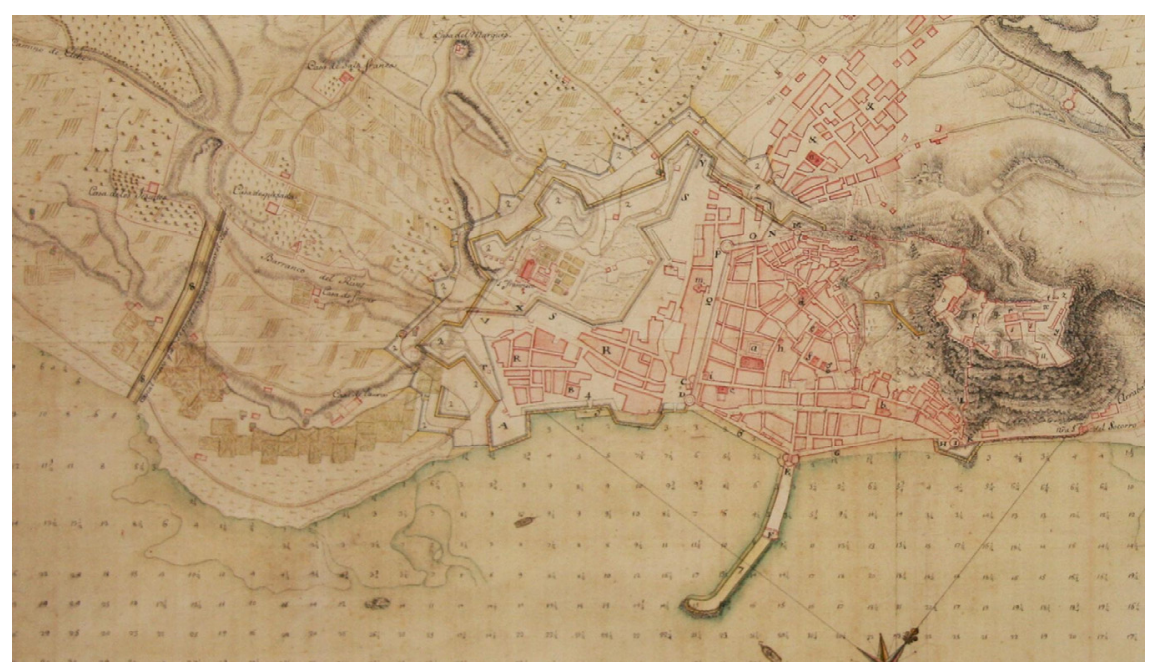

Figure 4: City plan, Castle and Port of Alicante, Jorge Próspero de Verboom, 1721, SGE, Ar.G-T.3-C.3-297. 
During the War of Succession the English who had taken the city and the castle in 1706, dug a large trench which ran from the San Carlos bastion, leaving the Convent of San Francisco outside, and into the interior forming a new bastioned front. The line of the trench included the water course of the San Blas gully which made a wide curve towards the sea opening out near the San Carlos bastion [8]. This arrangement was not at all advantageous for the city and its fortification because at times the water levels rose considerably causing torrential steams. In later years it would be necessary to resolve the diversion of water in both water courses of San Blas and Canicia [9].

The works to open up a new canal in order to divert the source of the San Blas gully were planned by Verboom in 1721 (Fig. 1). His proposal was part of the General Plan drawn up by the engineer, unquestionably the best project for the Alicante fortifications in the whole of its history [10].

\section{Start of the canal in $\mathbf{1 7 7 2}$}

Following some devastating floods such as those of 1752, which seriously affected the San Carlos bastion and the trench built by the English in May 1772, work began on the long desired canal. The project was overseen by Antonio Marín, Engineer and commandant of the Alicante square. In order to close the flow of water to the former water course, a breakwater was built consisting of earthworks covered by stone wall which diverted water from the San Blas gully directly to the sea similar to Verboom's original idea in 1721. However opening up a new canal was not a satisfactory solution. The terrain consisted of soft rock and not earth as was originally thought, and the excavations were extremely difficult. Furthermore the river bed had counterslopes and cavities in the area close to the exit road to Madrid, which produced whirlpools and had devastating effects on the breakwater.

Not only the San Blas gully, but also that of Canicia, which reached the city from the northeast, caused damage whenever there were heavy rains. Its natural route was the current Rambla de Méndez Núñez. Therefore it entered the city through part of the trench, causing problems in the trading warehouses and other buildings. The City Council, the Consulate of the port authority and city trade tried by every means possible to obtain permission to close the entry grills of these waters to the city whereas those on the side of war did everything in their power to prevent this happening. This arrangement entailed making the waters flow through the trench, the Bavel front and the San Carlos bastion, and inevitably caused damage to the walls and foundations. The solution to the problem was a complex one.

The badly constructed works of the new canal gave way in 1783 with fierce torrents of water flowing through again causing considerable damage to the San Carlos bastion. It required urgent repairs. Some interesting new projects were designed such as those of 1783, 1785 and 1786, by the engineers Pedro Antonio Molina, Antonio Exarch, and Baîme Anphoux, respectively. Subsequently there were further similar projects designed by Carlos Desnaux and the Conde de Aranda, who intervened, urged by the City Council, the Consulate and the city's 
traders. The most interesting project was designed in 1792 by Gerónimo de la Rocha y Figueroa, Engineer and Commandant of Alicante stronghold, following new damage suffered as a result of the rains of the previous year. The problem was adequately resolved but the solution did not satisfy the city. It consisted of a "portion of covered ditch in the Trincheron trench from the port of San Francisco to the stone grills; and raising two beds on the pavements of the Barranquet street". The waters continued to enter the walls, although with measures to prevent damage to the buildings, and only in the case of heavy rains would the overflow of water drain through the San Francisco trench. Its goal was to preserve at all cost any possible damage to the city fortifications.

In the early hours of 7 to 8 September 1793, further fierce torrents of water poured in, this time through the San Blas gully, which seems to have been forgotten over the years by the engineers responsible and the civil authorities alike, perhaps because it was the Canicia waters that had caused the most damage in recent times. The effects on the San Carlos bastion were devastating. The Canicia had also caused problems in some buildings in the interior. Despite the royal approval for the works they were not carried out. The debate continued over who was responsible for the cost.

\section{The military engineer, Leandro Badarán's plan: a proposal with three variants}

The latent preoccupation with the possibility of French troops disembarking in Alicante revived the need to protect the city from attack. It was unlikely that the enemy would attack a city fortified with a castle with such natural defences, however, the military engineers were commissioned to carry out a reconnaissance of the fortifications, and assess their situation, their defects and the artillery available. The Mayor of Alicante Josef Romeo ordered the report. It was drawn up by Leandro Badarán, Chief Engineer of the Cartagena fortification works, who was asked to take on the task given his experience and skills in the field [11].

Leandro Badarán's professional qualifications have not been studied in any depth until now. Through examination of the documentation preserved at the Institute of Military History and Culture in the copy directed by Aparici in the 19th century XIX on documents in the Simancas General Archive, and Capel's works on military engineers in Spain in the 18th century XVIII [12], it is possible to sketch a brief outline. We know that in 1763 he was Sub-lieutenant of Engineers which according to Royal Decree of 1756 was that of Draughtsman Engineer. That same year he left Valencia to work in Navarra. In 1773 he was transferred to Galicia, remaining there only for a short time, as we know that he carried out several civil architecture and religious projects in Chile from 1775 to 1785-1786, when he was transferred from La Coruña to Extremadura. He must have stayed there only a short time as that same year he signed the copy of a new project proposed for the total drainage of the Almajar de Cartagena, drawn up by Juan Ordovás. In 1788, having been assigned to Valencia, he was once more transferred to Cartagena. Until that moment he had risen progressively from 
Extraordinary Engineer to Ordinary and Second Engineer with a grade equivalent to Lieutenant Colonel. In October 1790 he worked in Orán, and from there he went to Alicante. He subsequently rose to the post of Chief Engineer in the district of Valencia, the rank just below the highest, that of Engineer General, a post which at the time of our research was held by Francisco Sabatini. From his work we can deduce that although he was not responsible for many fortification projects his work as an architect between 1774 and 1786 was prodigious. That experience was enriched by the project for channelling the river Mapocho in Chile in order to efficiently resist its surging torrents. This experience would be the best guarantee of his being commissioned to carry out his subsequent work in Alicante.

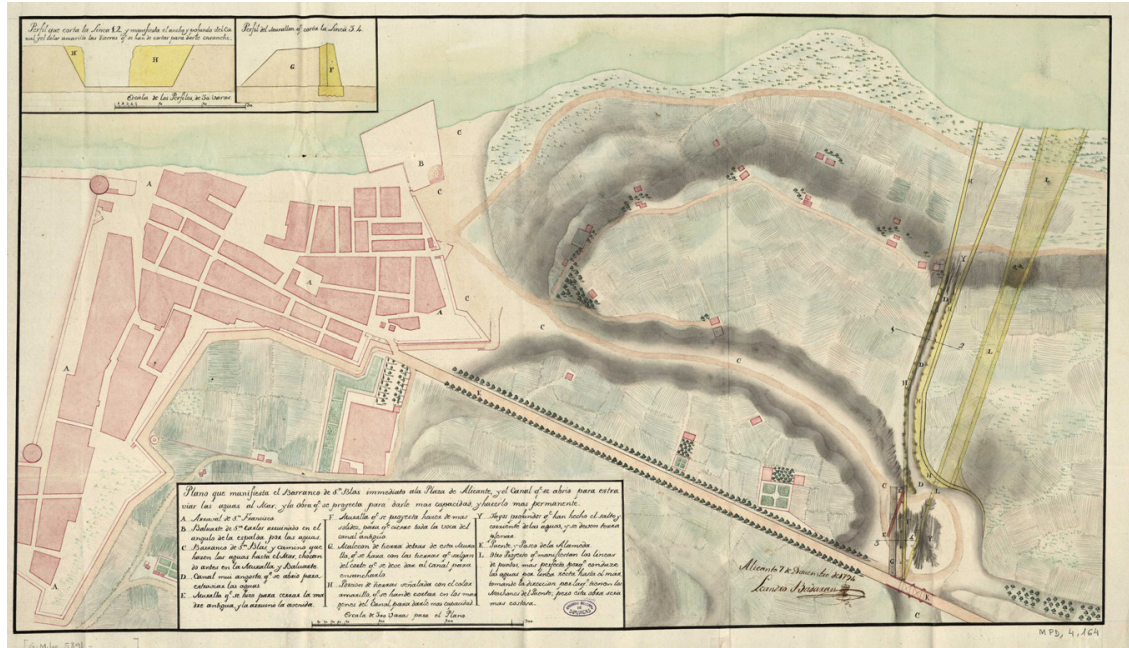

Figure 5: Plan showing the San Blas gully and the canal that was opened, Leandro Badarán, 7 December 1794, AGS. M, P and D. IV-164.

The Badarán report of 23 November 1794, is as accurate as it is extensive and provides a glimpse of his experience and knowledge in fortification matters [13]. His report could be summarised by saying that the large trench was extremely easy to attack, that all this part of the city was dominated by the Montañeta de San Francisco, that the San Antonio battery was hindered in its defence by the houses of the San Francisco neighbourhood and that the San Antón settlement outside the walls - could not be defended even from the castle. As to the San Carlos bastion, it was under threat from rifle fire from a small rise and therefore shoulders needed to be built to safeguard the batteries. The Castle of Santa Bárbara was not easy to attack or scale, however, it had the disadvantage that it could be attacked by battery from the mountain of San Julián, and therefore it was necessary to create bombproof arches in its buildings, in addition to protecting the batteries with shoulders of wooden planks or sacks of earth. He ordered a count of all the artillery pieces in the stronghold and proposed that some of the weapons should be diverted to Cartagena, a stronghold where a 
priori it would be easier for the enemy to disembark. In order to defend the castle of Alicante, 550 men were needed, 56 of whom would be artillery men and 168 would provide support to the artillery. There should be no more, as in the event of blockade they would consume too much food and water. In addition, there were not sufficient constructions to safeguard the troops. This report was submitted to the Court.

Soon after the report was drafted, on 7 December, Badarán once again drew up a new project to divert the source of the San Blas gully. Thus the king had ordered on the 26 May. It was based on the premise that prior to proceeding to repair the San Carlos bastion, the question of diverting the gully should be resolved. It was a priority as there was no point in repairing the bastion if there would be further flooding within the next few years. Looking back on the history of repairs carried out until that time, several errors stood out; firstly, the full width of the old canal had not been closed with the large wall, which moreover, had become considerably weak, and secondly the width of the new canal was insufficient.

The report was no less critical when evaluating "its failure to be in a straight line, or the direction of the right feet of the Bridge which is that which naturally carries the waters as they flow out". Because they flowed out obliquely with respect to the canal mouth - looping throughout its route - they were causing problems in the major wall. Finally, it was added that the fact that the earth walls of the water source were not cut with the natural inclination of their consistency was a disadvantage, as they collapsed more easily; the canal had not been extended to the sea; and the disadvantage that the levels of the canal bed were badly designed with "raised areas, dips and other unevenness" and the waters reached considerable speeds at some points. Many of these defects had been described in previous projects, however, the accuracy with which Badarán describes the causes which have led to these issues is striking.

There is no room here to refer to all the points of the project. It concerned construction of a large wall, able to align as adequately as possible the direction of the waters towards the canal, widening it and extending it to the sea, providing it with adequate earthworks. In the extension towards the sea it was appropriate to "continue the cut of the banks, making them wider at the end, as the plan states, so that the waters flow more freely, and have room to spread out, if anything detains them, there will be an inevitable meeting and swell from the sea water". He considered that the most important part of the project was to ensure a perfect plane of the canal bed with continuous inclination "which is such a slight inclination that it cannot cause any collapse or damage to the banks, as it would do if the water were to flow at a higher speed should the slope be greater. In order to create the base or plane of the Canal with this uniform inclination, all the dips and cracks would be filled in from the bridge up to the Canal entrance along with those in its mouth, using earth cut from its banks, treading down well, having been laid in layers, watered to ensure cohesion, and excavating or lowering the earthworks in some of the areas where they form high points". This technical prescription demonstrates the technical quality of Badarán's project. 


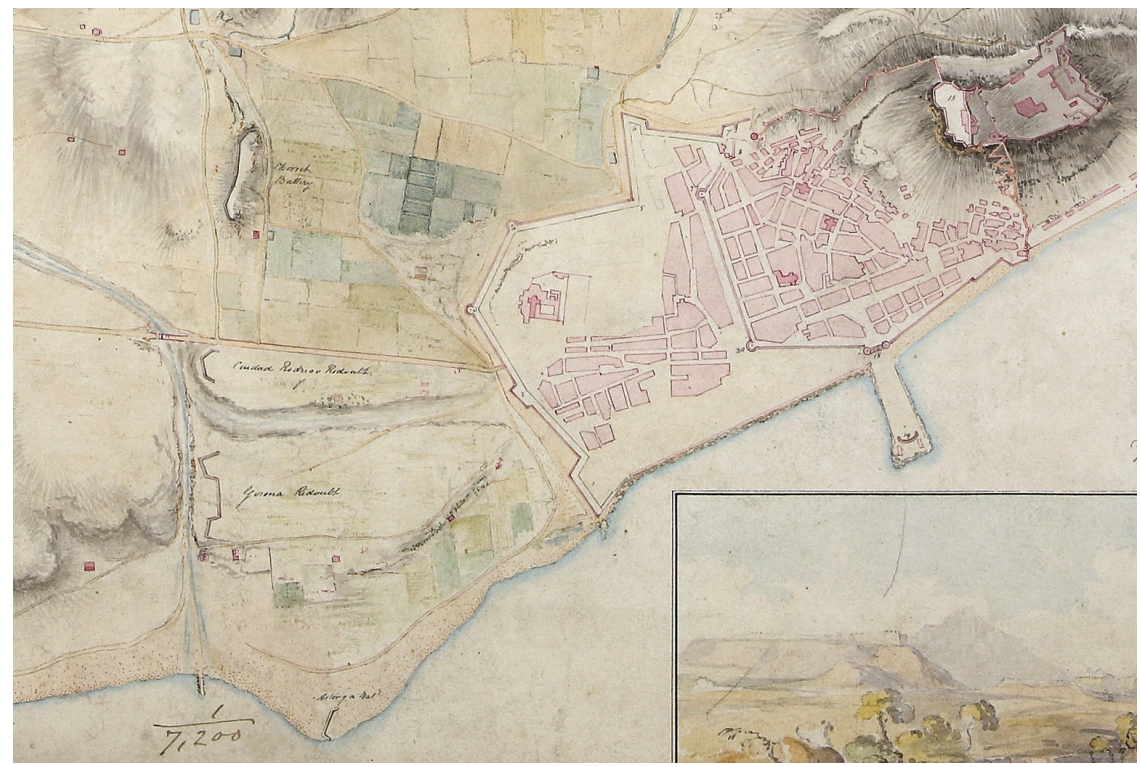

Figure 6: Detail of the plan of Alicante, surveyed and drawn by Henry du Vernet, 1812, National Archives, WO-78-1017-3-22.

In fact, the engineer showed three projects in one as the flow could be diverted in three ways. The first consisted of leaving the route of the watercourse as it was done in 1772, with the original attributes and forming a wall that would close the whole access to the former water course, reinforcing it with a breakwater using earth from the excavations to be carried out. The total cost would be 461.365 reales and 17 maravedis. The second method would be to create a totally new water course displaced to the west, and parallel with the existing one, in order to make the waters flow in a straight line. A similar wall would need to be constructed in order to close the flow to the former water course. The excavation earth would be dumped in the canal of 1772. The cost of the works would be 574.115 reales and 17 maravedis. And the third option was a simple variant on the first, in which Badarán was definitely taking a risk. The costs of materials and manpower had grown immeasurably in recent times, by a third more. And he saw removal of the wall as a way of reducing costs so that the task of directing the waters would be undertaken by the earth breakwater. In this way the cost of the works would be 317.450 reales. He recommended in every case making contracts per item or with piece work in order to make the works more economical.

On 18 February 1795, the Engineer General Francisco Sabatini decided that Badarán's project was too expensive, and that a way should be found to lower the cost [14]. He decided to follow Badarán's last proposal, removing the wall and making an earth breakwater with some small variations. The city and traders in Alicante would need to pay for the works, as they would be the ones who would gain the most benefit from the works. On 5 March the King approved 
Sabatini's proposal. We know through some plans and subsequent documents, especially those of the War of Independence, that the project for completing the new water course for the San Blas Gully was not implemented. Priority was given instead to constructing the fort of San Fernando, on the Tossal hill which overlooked the city.

\section{Conclusions}

During the 17th and 18th centuries the increased port activity in Alicante led to the need for extramural buildings beyond the fortifications to fulfil the needs of trade warehouses and residential settlements. During the War of Succession the English troops built a trench leaving the city of Alicante open to the devastating effects of the waters of the San Blas and Canicia gullies. This had negative consequences for the port, the fortifications and some buildings concerned with trade. Similar situations were experienced in the fortifications of other Mediterranean strongholds such as Gerona, Málaga or Cartagena.

In 1721 the General Engineer Jorge Próspero de Verboom drew up an ambitious project for the Alicante fortifications. It proposed diversion of the waters of the San Blas gully by means of a canal which would divert the flow of waters to the sea. In 1772 the canal was opened. It was built with scant financial resources and therefore the entire route was not constructed, its depth was not fully excavated and its base was not made sufficiently firm, and the former water source was closed off with a weak breakwater. Subsequent episodes of torrential flooding exposed these disadvantages. Between 1780 and 1798 some projects were drawn up in order to improve the canal. In 1794 the engineer Leandro Badarán offered three project alternatives based on the available resources. It was an intelligent project adapted to the scarcity of Treasury funds, and was supported with the collaboration of the city authority and tradesmen. The Engineer General Francisco Sabatini, opted for the third solution, a large wall raised and consisting solely of earth for diverting the waters. The king approved the project although it was never executed. The only investment in the city defence was made during the War of Independence with the construction of the fort of San Fernando.

\section{Acknowledgement}

This research contains some of the content already published by the author in Echarri Iribarren, Victor. "El desvio del cauce del barranco de San Blas en Alicante: proyectos realizados desde 1721 hasta 1787”, en Biblio 3W. Revista Bibliográfica de Geografía y Ciencias Sociales, [online], Barcelona: Universidad de Barcelona, 25 de diciembre de 2011, Vol. XVI, $n^{\circ} 954$.

\section{References}

[1] Muñoz Corbalán, Juan Miguel. Jorge Próspero de Verboom. Ingeniero Militar Flamenco de la Monarquía Hispánica. Fundación Juanelo Turriano. Madrid, 2013. 
[2] Cámara Muñoz, Alicia, "Les fortifications de la monarchie espagnole. Un système basé sur l'experience", en Warmoes, Isabelle. Vauban, bâtisseur du Roi-Soleil, París, Somogy éditions d'art, 2007; pp. 48-54.

[3] Pollak, Martha. Cities at War in Early Modern Europe. Cambridge: Cambridge University Press, 2010, 370 p.

[4] Cobos, Fernando, "La fortificación española en los siglos XVII y XVIII: Vauban sin Vauban y contra Vauban", en Silva Suárez, M. (ed.), Técnica e ingeniería en España. El siglo de las luces, Vol. II, Madrid, Real Academia de Ingeniería, Institución "Fernando el Católico", Zaragoza, Prensas Universitarias de Zaragoza, 2005, pp. 469-520.

[5] Capel, Horacio. Los proyectos del ingeniero Sebastián Feringán (1741) y de Francisco Boizot (1774) para el trasvase de los ríos Castril y Guardal, en Biblio 3W. Revista Bibliográfica de Geografía y Ciencias Sociales, Universidad de Barcelona, $\mathrm{n}^{\circ}$ 310, 7 de septiembre de 2001. http://www.ub.es/geocrit/b3w-310.htm

[6] Echarri Iribarren, V., Galiano Garrigós, A. "The controversies between Jacobo Fratín and Vespasian Gonzaga on the project of the citadel of Pamplona in the late sixteenth century", in WIT Transactions on the Built Environment, Vol. 143, 2014, pp. 65-76.

[7] Giménez López, Enrique. Alicante en el sigo XVIII. Economía de una ciudad portuaria en el antiguo régimen. Valencia: Institución Alfonso el Magnánimo, 1981.

[8] González Avilés, Ángel Benigno. "Mejoras en las fortificaciones abaluartadas de Alicante durante la Guerra de Sucesión", en Tiempos Modernos: Revista electrónica de historia moderna, 2012, vol. 7 n 25 .

[9] Echarri Iribarren, Victor. "El desvío del cauce del barranco de San Blas en Alicante: proyectos realizados desde 1721 hasta 1787", en Biblio $3 \mathrm{~W}$. Revista Bibliográfica de Geografia y Ciencias Sociales. [En línea]. Barcelona: Universidad de Barcelona, 25 de diciembre de 2011, Vol. XVI, $\mathrm{n}^{\circ}$ 954. http://www.ub.es/geocrit/b3w-954.htm

[10] Echarri Iribarren, Víctor. "El proyecto general para las fortificaciones de Alicante en 1721", en Hispania, Vol 74, n 2472014. http:/hispania.revistas.csic.es/index.php/hispania/article/view/431

[11] Echarri Iribarren, Víctor. "El desvío de los cauces de los barrancos de San Blas y Canicia en Alicante: proyectos realizados desde 1788 hasta 1798" en Biblio $3 W$ Revista Bibliográfica de Geografia y Ciencias Sociales, Vol. XVIII, no 1017, 15 de marzo de 2013. http://www.ub.edu/geocrit/ b3w-1017.htm

[12] Capel, Horacio, et al. Los ingenieros militares en España, siglo XVIII. Repertorio bibliográfico e inventario de su labor científica y espacial. Barcelona: Ediciones y Publicaciones de la Universidad de Barcelona (Colección "Geocrítica. Textos de Apoyo"), 1983. 495 p.

[13] Leandro Badarán's project for executing the San Blas gully canal. 7 December 1794. AGS. GM. Leg. 5891.

[14] Opinion issued by Francisco Sabatini submitted to the Ministry of War. 18 February 1795. AGS. GM. Leg. 5891. 